\title{
PRELIMINARY ASSESSMENT AND MITIGATING BY-CATCH OF EUROPEAN EEL IN A LONGLINE FISHERY IN BARDAWILL LAGOON, NORTH SINAI, EGYPT
}

M.S. Ahmed

Faculty of Aquaculture and Marine Fisheries, Arish University

\section{SUMMARY}

European eel, Anguilla anguilla is listed as critically endangered by the International Union for Conservation of Nature. Demersal longlines are the main fishing method used to target this species in Bardawill lagoon. Three trials were conducted to investigate catches (catch composition, catch rates, by-catch and CPUE) using hooks size No. 13, 12 and 11 from November, 2017 to January, 2018. Nine fishing trips (9 one trip days) were carried out. Within each trip, two longlines per hook size, each one involving 350 hooks, were set during sunset. After one hour, the longlines were pulled out. A total of nine species were recorded in all treatments, 1282 fish were caught, weighing a total of $194.71 \mathrm{~kg}$. Catch rates (number of fish per 100 hooks) ranged between 3.3 and 9.5, with a decrease in catch rate with increasing hook size. Mean TL of eel were significantly different among the three hooks. Eels caught on small hooks (No. 13 and 12) had a significantly smaller mean TL (mean TL $43.9 \mathrm{~cm}$ ) compared to eel caught on large hooks (No. 11, mean TL $45.1 \mathrm{~cm}$ ). Catch rates of small eel (mean TL $39.5 \mathrm{~cm}$ ) was highest in November followed by December and January. The highest CPUE was achieved when small hooks (No. 13) were used compared to large hooks (No. 11). To reduce capture of small eels (mean TL $45.1 \mathrm{~cm}$ ) fishermen in the demersal longline fishery in Bardawill Lagoon are encouraged to use large hooks (No. 11) with a bend width $\geq 12.7 \mathrm{~mm}$. Furthermore, future management measures should introduce minimum landing sizes for European eel to avoid capture of small eel (mean TL 45.1) and thereby reduce fishing mortality preventing stock degradation of these economic valuable species.

\section{Keywords: Demersal longline fisheries, Anguilla anguilla, hook size, Bardawill lagoon}

\section{INTRODUCTION}

The demersal longlines became widely used in Bardawill lagoon targeting European eel (Anguilla anguilla, Linnaeus 1758) alongside other species, that may be below the mature sizes. The European eel, spend part of its life in Bardawill lagoon, Eastern Mediterranean as a visitor in its complex life cycle which reproduces in the open ocean. European eel has been listed as critically endangered by the International Union for Conservation of Nature (Jacoby and Gollock, 2014) and in Annex II of the Convention on International Trade in Endangered Species of Wild Fauna and Flora to control its trade (CITES, 2014). Stocks of this species obviously declined and being no longer within biologically safe limits, over-exploitation one of the reasons for that (FAO and ICES, 2007; ICES, 2012 and 2014). In recent years, European eels were heavily exploited by hook and line fishermen in Bardawill lagoon. Globally, efforts must therefore be made to save this important species where that complex life cycle, the late reproduction and long life span of eels render them vulnerable to over-exploitation. Globally, Anguillan eel have sharp declines to less than $10 \%$ of their population levels compared to the $1970 \mathrm{~s}$, in recent decades (Jacoby et al., 2015), and stock of European eels remains critical (ICES, 2015). Aalto et $a l$., 2016 concluded that, research will have to focus on the south and east Mediterranean lagoons for studies on habitat loss, catches and effort of the European eel (hereinafter called 'eel'). Our noticing of longline fishermen indicate that juvenile eels (below $50 \mathrm{~cm} \mathrm{TL}$ ) constitute a high percentage in current catches using mostly hooks size No. 12 and 13. However, according to fishermen larger hooks (e.g. No 11) were not suitable for catching eel. So, a range of mitigation strategies should be applied to avoid catch of undersized eel by such fishing gear, where there is no legislation limiting the mean legal length (MLS). Thus, the current study aimed to provide a basis for determining the most suitable hooks size to reduce the capture of undersized eel in Bardawill lagoon.

\section{MATERIALS AND METHODS}

The study was carried out in Bardawill lagoon (Figure 1). The lagoon is a natural depression and covers an area of $\approx 650 \mathrm{~km}^{2}$ with a depth of 0.3 to 3 $\mathrm{m}$ (EEAA, 2008). It is located in the eastern Mediterranean Sea northern part of Sinai Peninsula, Egypt.

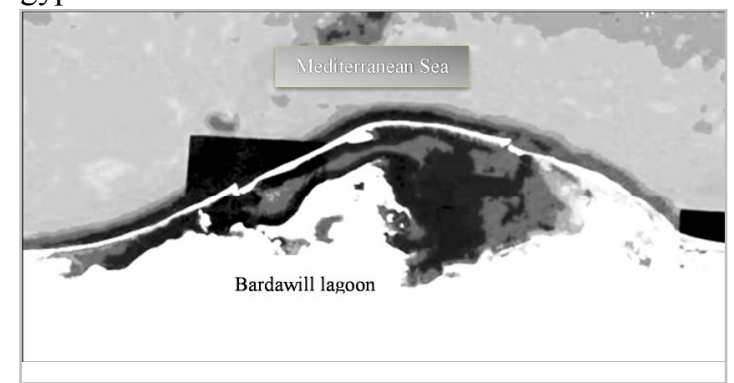

Figure 1. Map of Bardawill lagoon 
Demersal longlines operations targeting eel in the lagoon are restricted to the period between November and January. This study is based upon comparative catch data obtained from 27 fishing sets of different hooks sizes carried out in the demersal longlines fishery in Bardawill lagoon. The study was conducted between November 2017 and January 2018 (the traditional fishing season for this gear). Fishers operating in the lagoon use "J" style hooks size No. 13. After consultation of fishers, we used three J-style hooks for this study: Nos. 13 (with a bend width of $9.9 \mathrm{~mm}$ ), 12 (with a bend width of 11.5 $\mathrm{mm}$ ) and 11 (with a bend width of $12.7 \mathrm{~mm}$ ) as shown in (Figure 2).

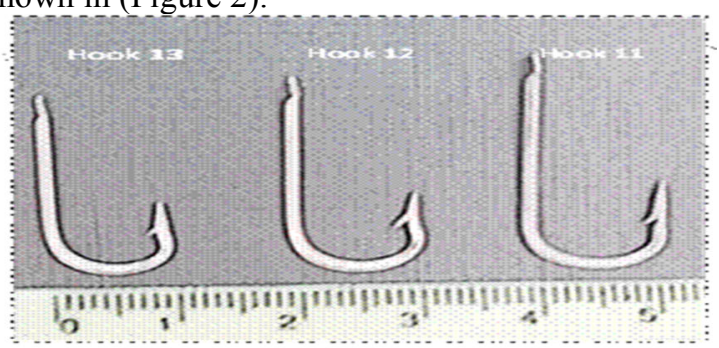

Figure 2. Shapes and dimensions of hooks

The fishing area was based on recommendation from fishers. These were characterized by sandy-mud habitat and depths ranging from 1.5 to $2.5 \mathrm{~m}$. The demersal longlines used in this study consisted of monofilament mainline $80 \mathrm{~mm}$ and $50 \mathrm{~mm}$ leaders. The space between leaders was approximately 2.85 $\mathrm{m}$. Each longline consisted of 350 hooks. Hooks were baited with small shrimp. Within each fishing trip, six longlines, two per treatment, were deployed. Fishing time was kept the same for all treatments.

During the study period, nine fishing trips (one fishing trip equaled one day) were carried out; three fishing trips per month. Longlines were set during the nights only and retrieved after approximately one hour. Catches were iced, labeled and transported to the laboratory for processing.

In the laboratory, catches were sorted by species and total length (TL) measured to the nearest $0.1 \mathrm{~cm}$ and weighed. Eel were classified into two groups: target (adult, $\geq 50 \mathrm{~cm} \mathrm{TL}$ ) and undersized (juvenile $<$ $50 \mathrm{~cm} T L$ ) to examine differences in catch rates by hook size. Length at first capture and minimum legal size were determined according to FAO database, annual reports of ICES and previous results (e.g. Eels (females) usually mature at sizes $>45 \mathrm{~cm}$ (Tesch, 2003; and Durif et al., 2005). The $50 \mathrm{~cm}$ body length corresponds to the legal minimum capture size of eel in Germany (Weltersbach et al., 2018), $60 \mathrm{~cm}$ in Sweden, $50 \mathrm{~cm}$ in Poland (ICES, 2014), and $55 \mathrm{~cm}$ in Estonia (Bernotas et al., 2016 and Silm et al., 2017). Also, Seabream $\left(L m_{50} \approx 21.6 \mathrm{~cm} \mathrm{Lt}\right.$, Salem, 2011) and Sea bass $\left(L m_{50} \approx 31.6 \mathrm{~cm} \mathrm{Lt}\right.$, Ameran et al. 2008). which below $L m_{50}$ were considered as undersized to allow spawning at least once before capture to sustain their stocks. All the rest of the catches were considered as a by-catch.

Length at first capture $\left(L c_{50}\right)$ value was determined for eel using the probability of capture from the pooled length frequency distribution curve. The catch data were standardized pooling all monthly fishing trips (2100 hooks). The mean Catch Per Unit Effort (CPUE) was calculated dividing the total weight $(\mathrm{kg})$ by the pooled monthly fishing trips $(2100$ hooks).

Differences in catch rates, sizes and mean CPUE of eel caught on different hook sizes (Each one $n=$ 6300 hooks) were assessed using ANOVA.

\section{RESULTS}

A total of nine species were recorded in all treatments, 1282 fish were caught, weighting a total of $194.71 \mathrm{~kg}$ (Table 1). Catch diversity decreased with increasing hook size. Decreasing hook size led to increase fish catches; $71.54,66.53$, and $56.64 \mathrm{Kg}$ with hooks size Nos. 13, 12 and 11, respectively. Catches were dominated by eel accounting for 81.7 $\%$ by number and $83.3 \%$ by weight, followed by a few species as Seabream (Sparus aurata) and Sea bass (Dicentrarchus labrax). There were significant differences $(\mathrm{p}<0.05)$ in numbers of eel caught by hook size. $46.4 \%$ of eels caught on small hooks (No. 13) versus $16.4 \%$ caught on large hooks (No. 11). Average total landing for eel caught on hook size No. 11 was significantly different than those caught by Nos. 13 and 12 hooks. Also, there were significant differences $(p<0.05)$ in mean TL for eel between hook size No. 11 and others and non-significant between Nos. 13 and 12. Means of TL were 43.9, 45.1 and $51.2 \mathrm{~cm}$ for each combination of hook size Nos. 13, 12 and 11, respectively. Sand flathead fish (Platycephalus bassensis) appeared in the catch in marked quantities as presented by $5.7 \%$ of total catches.

Mean catch rates (number of fish per 100 hooks) were $9.5,7.5$ and $3.3 \%$ for hooks size Nos. 13, 12 and 11 , respectively. Mean catch rates were significantly $(\mathrm{p}<0.05)$ influenced by hook sizes.

Length-frequency distributions of eel for each hook size followed normal distribution as shown in Figure 3. The distributions are overlapping (no significant of differences in catch frequency) between the smallest hooks (Nos. 13 and 12) and catch frequency was significant $(\mathrm{p}<0.1)$ decreases with the largest hook (No. 11). Lengths of eel ranged from 32 to $83 \mathrm{~cm}\left(L_{T}\right)$ for all hooks. The length distributions by hooks Nos. 13, 12 and 11 were 32 $72.5,32.1-74.5$ and $33.5-83 \mathrm{~cm}$, respectively 
Table 1. Catches of species (number and weight) in three hooks size

\begin{tabular}{|c|c|c|c|c|c|c|c|c|c|c|c|c|c|c|c|c|}
\hline \multirow{2}{*}{ Species } & \multicolumn{3}{|c|}{ Hook size 13} & \multicolumn{4}{|c|}{ Hook size 12} & \multicolumn{5}{|c|}{ Hook size 11} & \multirow{2}{*}{$\begin{array}{c}\text { Total } \\
\text { no } \\
\end{array}$} & \multirow{2}{*}{$\%$} & \multirow{2}{*}{$\begin{array}{r}\text { Total } \\
\text { Wt } \\
\end{array}$} & \multirow{2}{*}{$\%$} \\
\hline & no & $\mathbf{L}(\mathbf{c m})$ & S.D. & TW (Kg) & no & $\mathbf{L}(\mathbf{c m})$ & S.D. & TW (Kg) & no & $\mathbf{L}(\mathbf{c m})$ & S.D. & TW (Kg) & & & & \\
\hline \multicolumn{17}{|l|}{ Anguillidae } \\
\hline Anguilla anguilla & 485 & 43.9 & 7.58 & 61.548 & 391 & 45.1 & 8.86 & 56.925 & 172 & 51.2 & 11.83 & 43.645 & 1048 & 81.7 & 162.1 & 83.3 \\
\hline \multicolumn{17}{|l|}{ Sparidae } \\
\hline Sparus aurata & 14 & 20.0 & 1.58 & 1.664 & 7 & 21.7 & 2.41 & 1.192 & 2 & 22.8 & 1.05 & 0.395 & 23 & 1.8 & 3.3 & 1.7 \\
\hline Diplodus sargus & 2 & 15.8 & 0.90 & 0.148 & & & & & & & & & 2 & 0.2 & 0.1 & 0.1 \\
\hline \multicolumn{17}{|l|}{ Moronidae } \\
\hline Dicentrarchus labrax & 23 & 23.6 & 4.46 & 3.266 & 17 & 25.2 & 4.21 & 2.776 & 21 & 33.5 & 8.19 & 9.572 & 61 & 4.8 & 15.6 & 8.0 \\
\hline Dicentrarchus punctatus & & & & & 1 & 27.3 & & 0.151 & & & & & 1 & 0.1 & 0.2 & 0.1 \\
\hline \multicolumn{17}{|l|}{ Platycephalidae } \\
\hline Platycephalus bassensis & 59 & 20.8 & 3.28 & 4.456 & 50 & 22.5 & 3.14 & 4.781 & 11 & 25.5 & 2.88 & 1.777 & 120 & 9.4 & 11.0 & 5.7 \\
\hline \multicolumn{17}{|l|}{ Terapontidae } \\
\hline Terapon puta & 14 & 13.2 & 2.04 & 0.309 & 3 & 14.7 & 1.25 & 0.129 & & & & & 17 & 1.3 & 0.4 & 0.2 \\
\hline \multicolumn{17}{|l|}{ Sciaenidae } \\
\hline Croakers & & & & & & & 2.25 & 0.135 & 1 & 31.2 & & 0.313 & 3 & 0.2 & 0.4 & 0.2 \\
\hline \multicolumn{17}{|l|}{ Serranidae } \\
\hline Groupers & 2 & 20.0 & 2.35 & 0.146 & 3 & & 3.50 & 0.442 & 2 & & 3.85 & 0.943 & 7 & 0.5 & 1.5 & 0.8 \\
\hline Total & 599 & & & 71.536 & 474 & & & 66.531 & 209 & & & 56.64 & 1282 & & 194.712 & \\
\hline
\end{tabular}



Figure 3. Length frequency distribution of eels caught with various hooks sizes

Results indicated that, catch of undersized individuals and non-targeted species were significant $(p<0.05)$ and affected by hooks size. The highest catch of undersized eel ( 489 out of 599 individuals by numbers and $60 \%$ by weight of total catches) was recorded with the smallest hook size (No. 13), 356 out of 474 and 108 out of 209 individuals by numbers as undersized eel and 50.8 and $23.2 \%$ by weight of total catches was recorded for hooks Nos. 12 and 11, respectively (Table 2 and Fig.4).

Table 2. Target and undersized of species (number and weight) for three hooks sizes

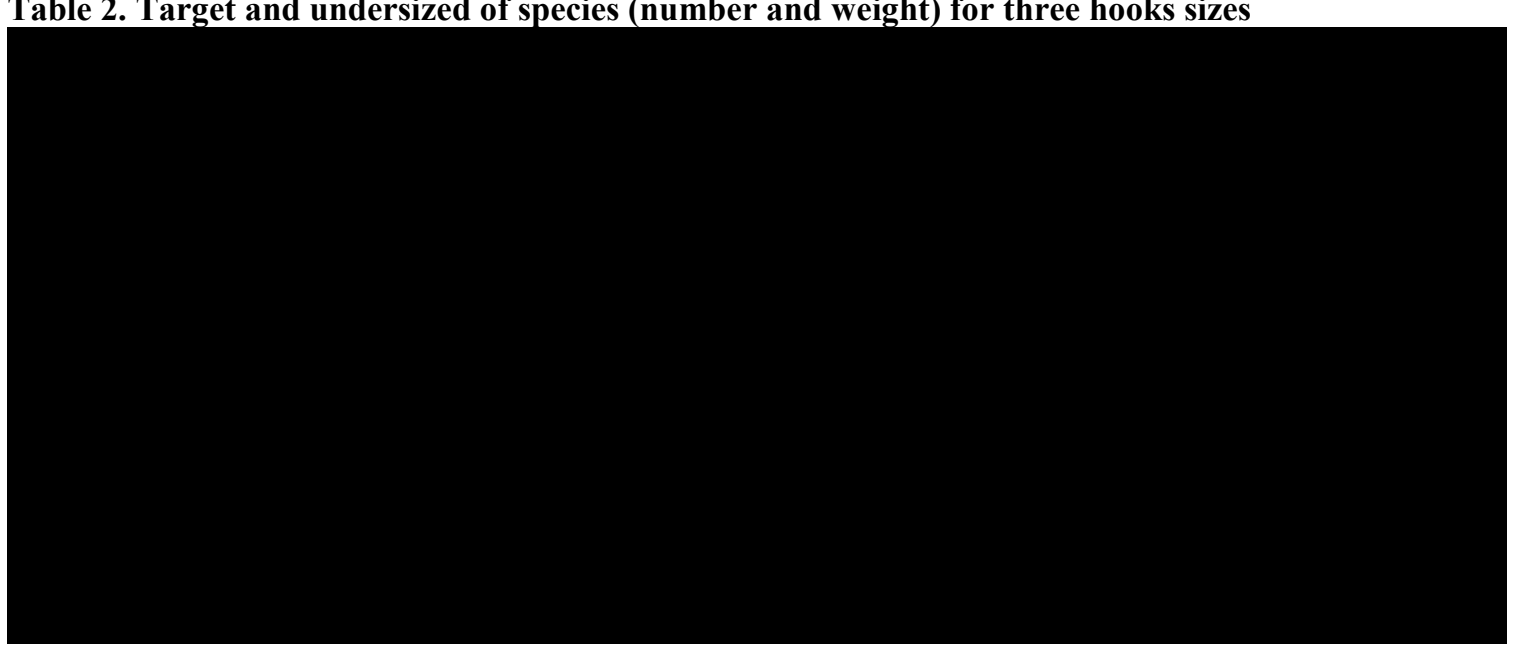




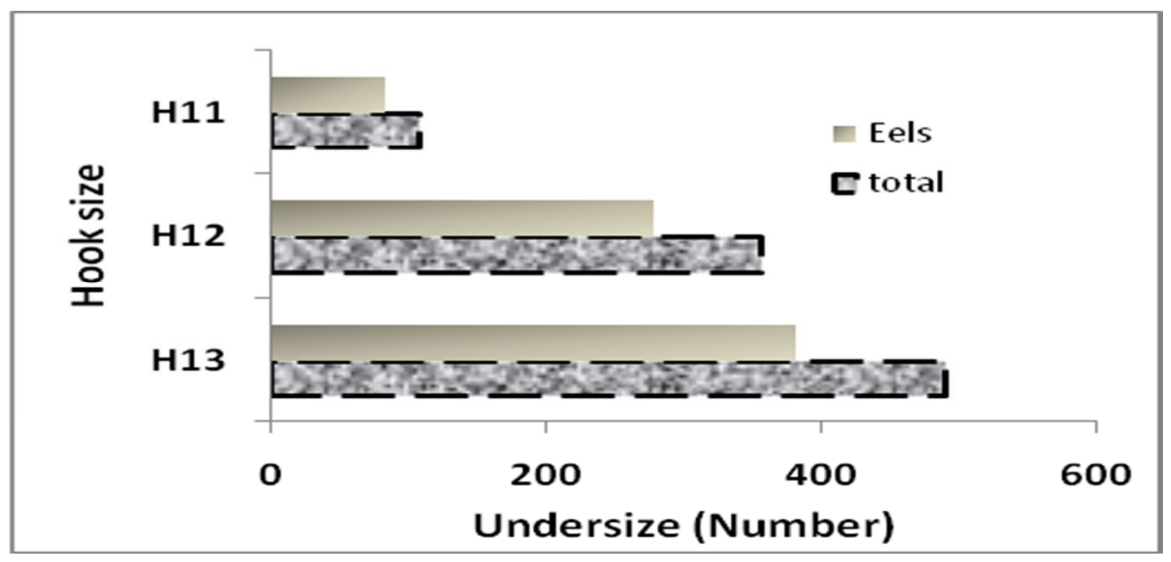

Figure 4. Undersize of eel in hooks size

Monthly, catch rates of undersized eel varied considerably. Catches of undersized eel (mean TL $39.5 \mathrm{~cm}$ ) accounted for $80 \%$ (numbers) and $52.5 \%$ (weight) of the total catch in November followed by December, 72.9 and $44.9 \%$ and January 67.2 and $40 \%$ respectively (Table 3 ).

There were overlapping lengths at first capture $\left(\mathrm{Lc}_{50}\right)$ of eel between hooks Nos. 13 and 12 for the smaller lengths (undersized), but higher lengths as hook size increased indicating that eel size significantly increased with increasing hook size (Figure 5). The $\mathrm{Lc}_{50}$ was $42,42.1$ and $50 \mathrm{~cm}$ for eel captured with Nos. 13, 12 and 11-hooks, respectively.

\section{Table 3. Monthly catches of adult and undersized eel (number and weight) for different hooks sizes.}
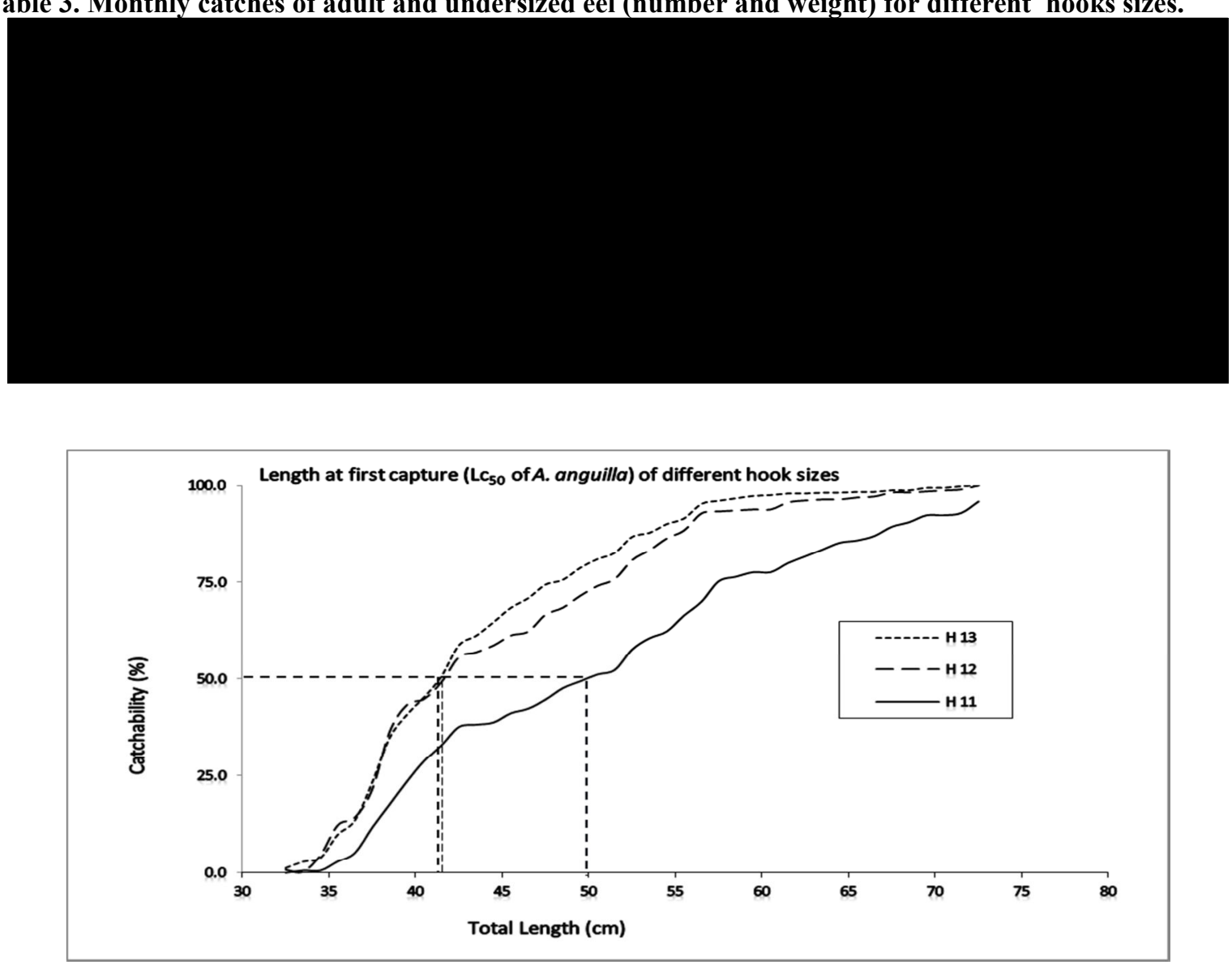

Figure 5. The length at first capture (Lc50) of eel for different hooks sizes.

The highest CPUE (23.85 Kg/boat/fishing day) was achieved by hook size No. 13, while the lowest CPUE (18.88 Kg/boat/fishing day) was achieved by hook size No. 11 and catches by hook size No. 12 were $22.18 \mathrm{Kg} /$ boat/fishing day respectively (Figure $6)$. 


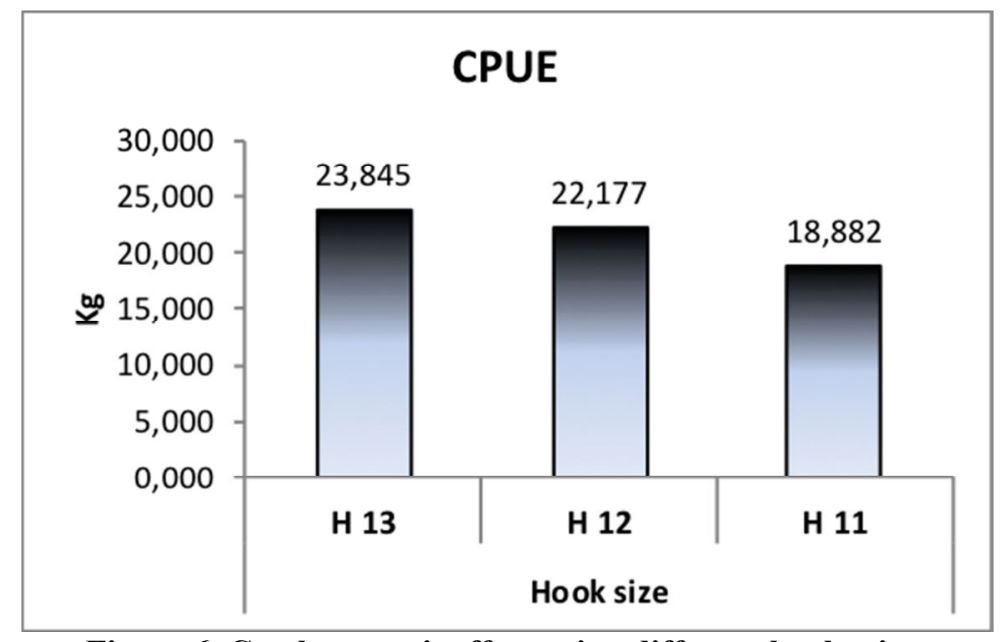

Figure 6. Catch per unit effort using different hooks sizes

\section{DISCUSSION}

This study provides a preliminary assessment of the impact of different hook sizes on the catch of European eel, since there is no legislation limiting hook and line gear, which needs to be taken into account for future fishing operations in Bardawill lagoon. There is a lack of information on line gear, catch composition; catch rates and factors which affect them. The total weight of eel in the use of small hooks was significantly higher compared to large hooks. Hook size affected not only the numbers and weights of individuals caught, but also the diversity of the catch as a whole. Bream and terapon fishes were captured with hooks No. 13 and 12 only. The numbers and species composition of fish caught can be influenced by a number of variables such as hook size and design (Erzini et al., 1998) where they found that, smaller hooks (No. 15 and 13) caught more breams (Sparidae) than larger hooks (No. 11). Landings in weight and the diversity of species caught were lower with large hooks (No. 11). Decreasing the hook size led to higher catch rates of most species. Results indicated significant differences in target eel size and catch rate (number and weight) between the commonly used hook size (No. 13) and the other two hook sizes (Nos. 11 and 12) used in this study. This result was confirmed by previous studies as Otway and Craig (1993), Alos et al. (2008) and Mongeon et al. (2013) which found an inverse relationship between catch rates and hook size where generally smaller hooks gave higher catch rates than larger ones. In a study conducted by Patterson et al. (2012) on the size of circle hooks, they found that, increasing hook size led to increased capture size and greatly diminished the diversity of the catch. This result differed from Ralston (1982); Bertrand, (1988), Fernö and Olsen (1994) which noted that different hook sizes did not notably modify catches.

Results showed apparent lack of differences in size distribution between small hooks and little evidence with the large hook while there were negatively relation among hooks size and the catch rates as the greater proportion of catch was achieved smaller hooks. Therefore, the hooks size could impact fishing effort and change the dynamics of eel. These results were confirmed by Erzini et al., 1999 in a study on different hook sizes, where they found the highest catch rates were obtained with the smallest hook. Catch rates are influenced by a number of variables in fisheries as hook size (Piovano et al., 2010). Decline in catch rate with increasing hook size for all fishes was observed by Garner et al. (2014).

In spite of, peak frequency sizes of eel that has been caught in the all hooks were small $(35-45 \mathrm{~cm})$, increased of hook size led to catch the large fishes while reducing the number of smaller fish. Though the general overlapping of length frequency curves of different hook sizes, a size 11 hook offers the best result to reduce the young eels in fishery. The size of the hook affects the structure of the size and distribution of the length of the catch (Punt et al., 1996 and Bayse and Kerstetter, 2010). It is not surprising that the catch size-frequency distributions of the different-sized hooks were often overlapping (Erzini et al., 1996; 1997 and 1999).

By-catch is critical component of fisheries management, as catch of undersized fishes and nontargeted species represented a global fisheries problem (Davies et al., 2009). The present work revealed that landings of by-catch species were much higher for the small size hooks than for the large size hook. By-catch is high ( $>100 \%$ of targeted landings), moderate and low with hooks size No. 13, 12 and 11 
respectively. This results that is consistent with previous research as Bacheler and Buchel, 2004. Hooks size was effective strategy to mitigate bycatch in demersal longline fishery especially of the European eels. By-catch in 11 and 12-hook sizes are a contributing factor to the decline of threatened species as eels, basses and breams fishes. By-catch in 11 -hook size is moderate (23.2\% of total landings) and does not include endangered species as breams fish. The size of the hook may be more important to impact on by-catch and small size of hooks that cause heavy fishing pressure on juveniles (Durai et al., 2011 and FAO, 2014). Selectivity of the hooks is due to the choice of the hook itself in relation to the size of the fish. Small-sized fish can swallow a hook no bigger than a certain size. While large fish escape from that small size of hooks where the small hooks cannot hooked the large fishes. Portion loss has already been observed of the large fishes during the fishing operation by the small hooks. Therefore, by changing the size of the hook can control the side catch of small-sized fish satisfactorily. The results show that most of the catch was under $50 \mathrm{~cm}$ in length, more than $73 \%$ under the legal size of all eels catch. The results suggest that could be decreased the smaller sizes of eels by hook size regulations, where fishers can significantly decrease the catch of small eels by using hook size No. 11 instead of Hook No. 13 , however, it is difficult to eliminate the catching of young eels. This result corresponds with the findings of Campbell et al. (2014). In a study by Weltersbach et al. (2018), showed that anglers can reduce catch of small eels by appropriate hook choice. The increase of by-catch during November was due to the large diversity of stocks during that period and the increase in feeding activity compared to other months, e.g. Bream fish migrate in the latter half of November and the feeding activity of Terapon fish is reduced in December and January.

Although hooks size Nos. 13 and 12 could be regulate the lengths at first capture $\left(L c_{50}\right)$ of target sizes of eels, the overlapping of the small lengths indicate that hooks would not mitigate undersized catch. Large hook No. 11 may be the most appropriate hook to use. Increasing the hook size used in a fishery can exclude undersized fish (Alos et al. 2008 and Campbell et al., 2014).

The results showed a significant increase in CPUE using the small hook. Similar results were obtained by Halliday, 2002. The smaller hook is the most widely used by fishermen and provides the best results for them in the short term, but it may be destructive to eel stock and some other important species in the long term.

\section{CONCLUSION}

Study suggest that hooks size Nos. 13 and 12 regulations do not efficiently target sizes to achieve reductions in by-catch, the by-catch and juveniles were negligible in the catches of hook No. 11. In the case of hooks Nos.13 and 12 by-catch and juveniles accounted dangerous numbers. To avoid catching non-target species or to reduce juveniles, then the largest hook (No. 11) should be the most preferable hook choice. Also, Eels of less than $40 \mathrm{~cm}$ should be released if caught by fishers. Fishing should be prevented by this gear during November of each year due to the high by-catches in this period, especially of bream fish. These are important recommendations for sustainable development of demersal longline fisheries in Bardawill lagoon, Eastern Mediterranean Sea.

\section{ACKNOWLEDGEMENT}

Author would like to thank the General Authority for Fisheries Development with special thanks to the management of Bardawill lagoon for technical support and facilitation of work.

\section{REFERENCES}

Aalto, E., F. Capoccioni, J. Terradez, M. Schiavina, C. Leone, G. De Leo and E. Ciccotti, 2016. Quantifying 60 years of declining European eel (Anguilla anguilla L., 1758) fishery yields in Mediterranean coastal lagoons. ICES J. Mar. Sci., 73, 101-110.

Alos, J., M. Cerd, S. Deudero, and A.M. Grau, 2008. Influence of hook size and type on short-term mortality, hooking location and size selectivity in a Spanish recreational fishery. Journal of Applied Ichthyology, 24:658-663.

Ameran, M., M. Salem, A. El-Aiatt, 2008. Age, growth and mortality of the sea bass, Dicentrarachus labrax from the Bardawil lagoon, North Sinai, Egypt. J. Egypt. Acad. Soci. Environ. Develop, 9 (2):1110-8770.

Bacheler, N.M. and J.A. Buchel, 2004. Does hook type influence the catch rate, size, and injury of grouper in a North Carolina commercial fishery? Fish. Res. 69: 303-311.

Bayse, S. and D. Kerstetter, 2010. Assessing bycatch reduction potential of variable strength hooks for pilot whales in a western north Atlantic pelagic longline fishery. J N. C. Acad Sci 126: 6-14.

Bernotas, P., M. Vetemaa, L. Saks, R. Eschbaum, A. Verliin and A. Järvalt, 2016. Dynamics of European eel landings and stocks in the coastal waters of Estonia. ICES Journal of Marine Science, 73(1): 84-90.

Bertrand, J., 1988. Selectivity of hooks in the handline fishery of the Saya de Maiha Banks (Indian Ocean). Fish. Res. 6: 249-255.

Campbell, M.D., A. Pollack, W.B. Driggers, B. Sauls, J. Walter and E.R., Hoffmayer, 2014. Estimation of Hook Selectivity of Red Snapper and Vermilion Snapper from Fishery-Independent Surveys of Natural Reefs in the Northern Gulf of Mexico Marine and Coastal Fisheries: Dynamics, Management, and Ecosystem Science 6: 260-273

CITES, 2014. Convention on International Trade in Endangered Species of Wild Fauna and Flora, Appendices I, II and III. https://www.cites.org/. 
Davies RWD, S.J. Cripps, A. Nickson, G. Porter, 2009. Defining and estimating global marine fisheries bycatch. Marine Policy 33: 661-672. doi: 10.1016/j.marpol.2009.01.003.

Durai, V., N. Neethiselvan, B. Chrisolite and B. Sundaramoorthy, 2011. Longline selectivity and fishing pressure on the fishery of Lethrinus elongatus off thoothukudi coast. Tamilnadu J. Veterinary \& Animal Sciences 7 (3): 137-143.

Durif, C., Dufour, S. and P. Elie, 2005. The silvering process of Anguilla anguilla: a new classification from the yellow resident to the silver migrating stage. Journal of Fish Biology, 66: 1025-1043.

Erzini, K., J. M. S. Gonçalves, L. Bentes, P. G. Lino and J. Cruz. 1996. Species and size selectivity in a Portuguese multispecies artisanal long-line fishery. ICES. J. Mar. Sci. 53: 811-819.

EEAA (Egyptian Environmental Affairs Agency), 2008. Egypt State of Environment Report. 356 pp.

Erzini, K., J.M.S. Gonçalves, L. Bentes and P. G. Lino. 1997. Mouth size and hook selectivity in a multispecies artisanal long-line fishery. J. Appl. Ichthyol. 13: 41-44.

Erzini, K., J.M.S. Goncalves, L. Bentes, P.G. Lino and J. Ribeiro, 1998. Species and size selectivity in a 'red' sea bream longline 'metier' in the Algarve (Southern Portugal). Aquatic Living Resources, 11: 1-11.

Erzini, K., J.M.S. Gonçalves, L. Bentes, P.J. Lino and J. Ribeiro, 1999. Catch composition, catch rates and size selectivity of three long-line methods in the Algarve

(southern Portugal). Bol. Inst. Esp. Oceanogr. 15 (14): 313-323.

FAO and ICES (International Council for the Exploration of the Sea), 2007. Report of the 2007 Session of the Joint EIFAC/ICES Working Group on Eels. F.C. ICES CM 2007/ACFM: 23. Rome, Italy (138 pp.)

FAO. 2014. By-catch in longline fisheries for tuna and tuna-like species: a global review of status and mitigation measures. A global review of status and mitigation measures. FAO Fisheries and Aquaculture Technical Paper No. 588. Rome, FAO. 199 pp.

Fernö, A. and S. Olsen, 1994. Marine fish behaviour in capture and abundance estimation. Fishing News Books 94-7919. Oxford, UK.

Garner, S.B., F.P. William, Porch C.E. and Tarnecki J.H., 2014. Experimental Assessment of Circle Hook Performance and Selectivity in the Northern Gulf of Mexico Recreational Reef Fish Fishery, Marine and Coastal Fisheries, 6:1, 235246.

Halliday, R.G., 2002. A comparison of size selection of Atlantic cod (Gadus morhua) and haddock
(Melanogrammus aeglefinus) by bottom longlines and otter trawls. Fisheries Research, 57: 63-73.

ICES (International Council for the Exploration of the Sea), 2012. Report of the 2012 session of the Joint EIFAC/ICES Working Group on Eels. CM2012/ACOM, 18،824pp.

ICES, 2014. Report of the Joint EIFAAC/ICES/GFCM Working Group on Eel, 37 November 2014, Rome, Italy. ICESCM2014/ACOM: 18. 203 pp.

ICES, 2015. Report of the Workshop of a Planning Group on the Monitoring of Eel Quality under the subject "Development of standardized and harmonized protocols for the estimation of eel quality" (WKPGMEQ), 20-22 January 2015, Brussels, Belgium. ICES CM 2014/SSGEF:14. 274 pp.

ICES, 2016. Report of the joint EIFAAC/ICES/GFCM Working Group on Eel (WGEEL). Anatlya. 24-November- 2 December 2015. ICES CM 2015/ACOM:18. 869 p.

Jacoby, D., and M. Gollock, 2014. Anguilla. The IUCN Red List of Threatened Species 2014. www.iucnredlist.org.

Jacoby, D., J.M. Casselman, V. Crook, M.B. DeLucia, H. Ahn, K. Kaifu and T., Kurwie, 2015. Synergistic patterns of threat and the challenges facing global anguillid eel conservation. Glob. Ecol. Conserv. 4: 321-333.

Mongeon, C., E.F. Granek and R. Arauz, 2013. Hook Selectivity in an Artisanal Spotted Rose Snapper Lutjanus guttatus Fishery on the Nicoya Peninsula, Costa Rica. Marine and Coastal Fisheries: Dynamics, Management, and Ecosystem Science 5: 270-280.

Otway, N.M. and J.R. Craig, 1993. Effects of hook size on the catches of undersized snapper Pagrus auratus. Marine Ecology Progress Series 93: 915.

Patterson, W.F., C.E. Porch, J.H. Tarnecki, and A.J. Strelcheck. 2012. Effect of circle hook size on reef fish catch rates, species composition, and selectivity in the northern Gulf of Mexico recreational fishery. Bulletin of Marine Science 88: 647-665.

Piovano, S., S. Clo and C. Giacoma, 2010. Reducing longline bycatch: The larger the hook, the fewer the stingrays. Biological Conservation 143: 261264.

Punt, A.E., A. Pulfrich, D.S. Butterworth, and A.P. Penney, 1996. The effect of hook size on the sizespecific selectivity of hottentot Pachymetopon blochii (Val.) and on yield per recruit. S. Afr. J. Mar. Sci. 17: 155-172.

Ralston, S., 1982. Influence of hook size in the Hawaiian deep-sea handline fishery. Can. J. Fish. Aquat. Sci. 39: 1297- 1302. 
Salem, M., 2011. Population dynamics and fisheries management of Gilthead sea bream, Sparus aurata (f. Sparidae) from Bardawil lagoon, North Sinai, Egypt. Egypt J. Aquat. Biol. \& Fish., 15(1): 57- 69.

Silm M., P. Bernotas, M., Haldna A., Järvalt T., Nõges, 2017. Age and growth of European eel, Anguilla anguilla (Linnaeus, 1758), in Estonian lakes. J. Appl. Ichthyol. 33: 236-241. https://doi.org/10.1111/jai.13314
Tesch, F. W., 2003. The Eel. Blackwell Science, Oxford.

Weltersbach, M.S., H.V. Strehlow, K. Ferter, T. Klefoth, M. Graaf and M. Dorow, 2018. Estimating and mitigating post-release mortality of European eel by combining citizen science with a catch-and-release angling experiment. Fisheries Research 201: 98-108.

التقييم الأولي والتخفيف من المصيد العرضي للثعابين الأوروبية في مصيد الخيوط الطويلة بمنخفض البردويل، شمال سيناء ، مصر الاول و محمد سالم احمد كليه الاستزراع المائي والمصايد البحرية، جامعه العريش

تم إدراج ثعبان السكك الأوروبي (Anguilla anguilla) ضمن الاسماك المهددة بالانقراض من قبل الاتحاد الدولي للحفاظ على الطبيعة.

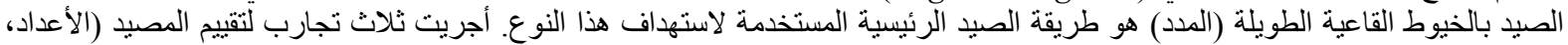



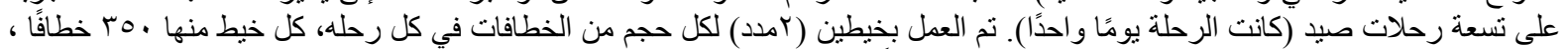

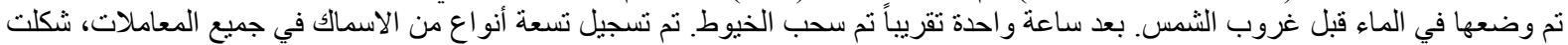

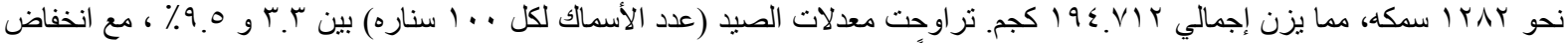

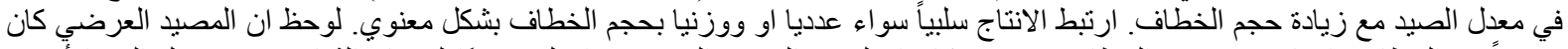



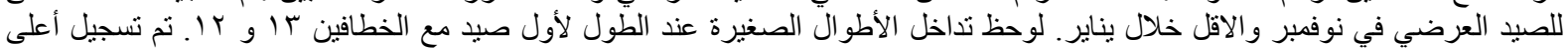

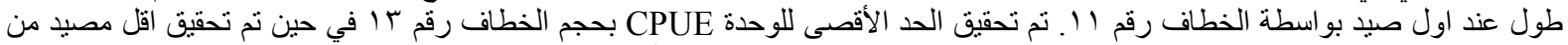





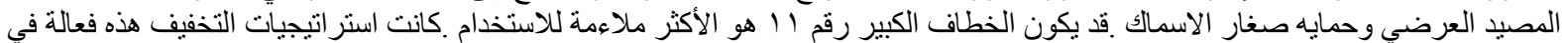
منع الصيد العرضي لمعظم الأنواع. 